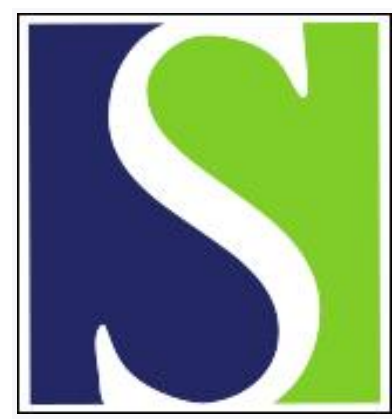

Scand J Work Environ Health 2011;37(5):363-375

https://doi.org/10.5271/sjweh.3159

Published online: 14 Mar 2011, Issue date: Sep 2011

Explicit and implicit theories of change when designing and implementing preventive ergonomics interventions - a systematic literature review

by Wijk K, Mathiassen SE

Affiliation: Centre for Musculoskeletal Research, Department of Occupational and Public Health Sciences, Faculty of Health and Occupational Studies, University of Gävle, SE-80176 Gävle, Sweden. katarina.wijk@hig.se

Refers to the following texts of the Journal: 2000;26(1):7-19 1999;25 suppl 4:25-30 2010;36(1):3-24 2002;28(1):18-24 2005;31 suppl 2:96-103

The following article refers to this text: 2017;43(6):526-539

Key terms: change process; ergonomics; implementation; intervention; intervention research; musculoskeletal; occupational; systematic review; theory of change

This article in PubMed: www.ncbi.nlm.nih.gov/pubmed/21403982 


\title{
Explicit and implicit theories of change when designing and implementing preventive ergonomics interventions - a systematic literature review
}

\author{
by Katarina Wijk, PhD, ${ }^{1}$ Svend Erik Mathiassen, $P h D^{1}$
}

\begin{abstract}
Wijk K, Mathiassen SE. Explicit and implicit theories of change when designing and implementing preventive ergonomics interventions - a systematic literature review. Scand J Work Environ Health 2011;37(5):363-375. doi:10.5271/sjweh.3159
\end{abstract}

\begin{abstract}
Objective In contrast to several previous papers dealing with the structure and effects of ergonomics interventions, this systematic literature review focuses on the theories concerning change processes upon which these interventions - implicitly or explicitly - have been based.

Methods In a systematic search of 13 literature databases, 30 peer-reviewed intervention studies published between 2000-2007 were identified that provided sufficient information for the change process theory to be identified.

Results Thirteen studies referred to an explicit theory of change, the most common being participatory theory, while in 17 studies, the change theory could only be discerned indirectly from the described intervention strategy. Twenty-five studies explained the reason for choosing their strategy, with a clear reference to theory or previous research, whereas five provided only a weak background. Four categories of intervention strategies for change were identified: (i) changes targeting the individual, (ii) changes focusing on the work environment, (iii) changes relying on interactions between people, and (iv) structural and organizational changes.

Conclusions A strikingly small proportion of ergonomics intervention studies have explained the theory behind the expected change process. A better awareness of the assumptions about change processes embedded in intervention strategies - whether implicit or explicit - may help in identifying and examining those ideas and processes that promote or restrict successful implementation. Such knowledge, in turn, can contribute to the development of interventions that are thoughtfully designed and effectively implemented.
\end{abstract}

Key terms change process; implementation; intervention research; musculoskeletal; occupational.

Work-related musculoskeletal disorders (MSD) are a major issue in public health (1-4). Ergonomics interventions are widely planned and implemented at workplaces in order to prevent work-related MSD and, at times, optimize production (5). Any such intervention will be preceded by setting up strategies expected to lead to the intended change and methods for realizing the strategies. The strategies, in turn, reflect implicit or explicit theories of how to succeed in creating change (6). While interventions based on a sound theory on processes leading to better health are not guaranteed to be successful, they are much more likely to reach the desired health outcomes than interventions not having a theoretical foundation (7). Theories can be defined as presumptions about causal relations (8) or as "ideas of causal relationships in a model showing what variables are assumed to be relevant and what influences are assumed to exist between those variables" [translation from Hellevik (9) p11]. French \& Adams (10) define a theory as "an explanation or system of anything, an exposition of the abstract principles of a science or art, speculation, a hypothesis or a reasoned explanation" (p71). Theories of change may be either explicitly explained when describing an intervention, or they can be implicit (11). Backman \& Kyngäs (12) stated with reference to Sandelowski (13) that while "... a theoretical orientation may not be explicitly stated in a qualitative project, or may even be denied, it is always implicit in the way a problem is presented, in the way the literature is reviewed and, most importantly, in the selection and description of the method itself".

In the context of ergonomics interventions, this means that an initiative aimed at a change involving

1 Centre for Musculoskeletal Research, Department of Occupational and Public Health Sciences, Faculty of Health and Occupational Studies, University of Gävle, SE-80176 Gävle, Sweden

Correspondence to: Katarina Wijk, Centre for Musculoskeletal Research, Department of Occupational and Public Health Sciences, Faculty of Health and Occupational Studies, University of Gävle, SE-80176 Gävle, Sweden. [E-mail: katarina.wijk@hig.se] 
staff and/or leaders will always rely on an explicit or unspoken idea of a cause and an effect, for example that an increased awareness of risks (cause) will lead to behavioral change (effect).

Several excellent reviews and numerous studies have been devoted to identifying work-related MSD risk factors (14-18), how to assess exposure to these risk factors (19-23), physiological mechanisms explaining MSD $(24,25)$, effective levels of action $(5,26,27)$, ergonomics effects of changes caused by rationalizations (28), and outcomes of interest to ergonomics interventions such as health $(29,30)$ and profitability $(31-33)$. While these issues are central to the understanding of how to design an effective intervention, they do not address the process of change per se.

Other reviews and position papers have focused in a general sense on principles or ideas of how to conduct interventions. Some studies have addressed theories or models underlying ergonomics interventions, yet without anchoring them into a specific/concrete intervention (eg, 34, 35). Others have discussed, in general terms, implementation strategies and methods (36-39), intervention processes $(40,41)$, or the necessity of combing evidence and theory when designing interventions (eg, 26). None of these studies, however, go behind the processes and strategies in an attempt to identify their theoretical basis. A few previous studies have dealt with issues closely related to change theories in realized ergonomics interventions, mainly by discussing the effectiveness of different intervention approaches. Thus, Westgaard \& Winkel (42) concluded more than ten years ago in a review of 92 studies that the most effective ergonomics interventions were either grounded in the organizational culture or focused on individual workers at risk, and that future ergonomics intervention research should emphasize the intervention process. Whysall et al (43) examined the effectiveness of using a behavioral change model called the stage-of-change theory, based on the notion that any change will develop through a number of stages. They reviewed 24 occupational health interventions followed for a period of 4-6 months and concluded that an approach involving stages of change may substantially improve the intervention efficacy. In a review of the effectiveness of participatory interventions, Rivilis et al (44) stated that those 12 studies that were of at least medium quality showed some evidence that participation had a positive impact on different indicators of musculoskeletal health. Brewer et al (45) examined the effects on musculoskeletal or visual health reported in 31 intervention studies in office settings, and concluded that few of the studies were of high quality, and that evidence was insufficient in many cases to conclude about intervention effectiveness. In a meta-review, Silverstein \& Clark (46) discussed 17 systematic review articles on interventions to reduce work-related MSD.
They concluded that multi-component interventions have a greater chance of being successful than interventions targeting single factors, and further, that modification of factors at the individual level do not appear to be particularly useful in preventing MSD

To our knowledge, no previous review in the scientific literature has been devoted to identifying explicit or implicit theoretical assumptions about change processes in ergonomics interventions that have actually been implemented at the workplace. A few papers have compared specific implementation approaches; for instance, Haines et al (47) defined a range of different participatory ergonomics initiatives and surveyed how seven case studies operated at different organizational levels, and Van der Molen et al (48) proposed a theoretical framework for structuring the implementation of interventions.

This review adds to the extensive literature on different aspects of ergonomics intervention by focusing on the issue of why interventions are implemented the way they are, in terms of underlying and overt assumptions about the expected change processes. Thus, the review addresses primarily the implementation phase of ergonomics interventions, emphasizing the chosen strategy and method for change, and the reason for selecting that approach. The review pays less attention to preceding steps in the intervention process (ie, identifying risks and their assumed causes, deciding for appropriate intervention targets on the basis of this analysis, and selecting relevant methods for assessing the effects of the intervention); it also omits whether the intervention led to the expected outcome (eg, in terms of better health). The reviews cited above deal with these aspects.

\section{Methods}

The Cochrane Collaboration methodological guideline for systematic reviews of interventions (49) was used as a lodestar for this study.

\section{Identification of publications}

A systematic search was conducted in the following 13 reference databases: Academic Search Elite, CINHAHL, CSA, EBSCOhost, EJS Journals, ERIC, ISI Web of Science, Medline, PAIS International, Pre-Chinahl, PsycInfo, PsycARTICLES, and Social Services Abstracts and Sociological Abstracts. These databases contain a total of approximately 15000 journals. The databases were selected with the help of an IT-librarian with special competence in scientific databases and by setting up a list of all scientific journals in the area of ergonomics, health and MSD known to the first author. This list was discussed with fellow researchers in the field and 
thus further developed. To determine the search terms, we identified keywords in titles, abstracts, and aims of published relevant articles in our possession. In addition, we carefully selected key concepts and synonyms thereof on the basis of lexicographic literature on our preliminary search terms. As an illustrative example, we read a review on the concept of work-related MSD and its synonyms (50). Multiple terms describing similar concepts, for instance Musculoske* OR Ergonomic were thus identified. Truncations of keywords, represented by the symbol*, were used to expand the search, for example, Work* expands to work place, work environment, Work-related low-back disorders, etc. When searching in the reference databases, each of the synonyms Occupat* and Work* was first combined with one of the following words: Intervention, Prevention, and then with one of the words Musculoske* and Ergonomic*.

The review was limited to studies published between 2000-2007. This was done primarily to ensure that research was up to date, and secondarily in order to allow extensive accessibility of articles on the Internet. In all, 2940 articles were identified in the databases; all abstracts were read to determine if the publication complied with the inclusion criteria set out below.

\section{Selection of publications - inclusion/exclusion criteria}

In order to be included in the review, articles had to comply with all of the following criteria: (i) published in a peer-reviewed scientific journal; (ii) written in English; (iii) reported a primary ergonomics intervention implemented in occupational life; and (iv) addressed the process of change including, eg, development, learning, training, and the actual change. Criteria (iii) and (iv) were operationalized by including articles that (a) explained their intervention as having an ergonomics purpose, eg, prevention of MSD or improvements of the physical work environment; (b) reported a concrete, implemented intervention; and (c) described the whole intervention process, that is planning, implementation and evaluation. Interventions testing or evaluating new technologies, equipment, or tools were only included if they also problematized the process of change, in other words, if they focused on not only the evaluation of the equipment but also how to succeed in having workers use that equipment as intended.

Some interventions were reported in more than one article (eg, 51-53). In such cases, only the most comprehensive article was included in the review.

Publications were excluded if belonging to any of the following categories: (i) books and grey literature; (ii) reports of secondary or tertiary interventions intended to treat present MSD or focused on reducing sick leave; (iii) interventions targeting work disability, patients, or injuries; or (iv) interventions evaluated only in laboratory studies.
The first author conducted the entire search procedure, which resulted in 30 articles being accepted into the review. The reference lists of all these articles were examined to identify possible further publications meeting the inclusion criteria but none were found.

\section{Data analysis strategy}

The taxonomy and analysis strategy for summarizing information about the published interventions was mainly inspired by the methodological guidelines in the Cochrane Handbook for Systematic Reviews of Interventions (54) and procedures used by Bos \& van Kammen (55), Brewer et al (45) and Oldenburg et al (56). Thus, each of the articles accepted for the review was examined and coded according to a standardized protocol (table 1).

Using this protocol, all articles were systematically analyzed. To begin with, the first author thoroughly read each article, extracted the desired data (table 1), and summarized them in a table. For studies considered to rely on an implicit theory, additional notes were taken concerning the strategy and alleged assumptions in the article. If, for instance, an intervention used the strategy of educating employees, this was interpreted as an implicit theory of more knowledge leading to change. Finally, studies were categorized into a two-by-two table combining the dimension explicit/implicit theory with an assessment of whether the intervention strategy was weakly or deeply rooted in a theory of change. This model has been used in previous research reviewing intervention theories (11). In a second stage, another reviewer with a post-graduate competence in pedagogical science repeated this process, blinded to the results of the first reviewer. The two reviewers then compared their data extraction protocols (table 1). In case of disagreement, both reviewers read the article again and continued discussions until consensus was reached. The reviewers compared their allocation of studies in the two-by-two table concerning theory and rooting, and disagreements were resolved in an iterative discussion leading to consensus. Finally, for the papers classified as relying on implicit theories, on the basis of their notes, the two reviewers thoroughly discussed their findings and interpretations of tacit assumptions and strategies. During this process, a third research assistant, with a degree in health education science, took part as a reflecting coach. In addition to the items listed in table 1, the reviewers also identified the intended outcomes of the interventions in each article. Since, however, the large majority of reviewed articles did not discuss whether the obtained outcome could be explained in the context of the applied theory of change, we chose not to address the relationship between theory and effectiveness in this review. A simple comparison of effectiveness between 
Table 1. Literature analysis protocol

\begin{tabular}{|c|c|}
\hline Code & Extracted items \\
\hline 1. Title & Title of the article \\
\hline 2. Author & Year of publication and name of the first author \\
\hline $\begin{array}{l}\text { 3. Subjects and } \\
\text { settings }\end{array}$ & $\begin{array}{l}\text { Description of participants (eg, occupations and } \\
\text { size of study population) and location of the } \\
\text { intervention }\end{array}$ \\
\hline 4. Study design & $\begin{array}{l}\text { Basic study design (eg, presence of a control } \\
\text { group) and duration of the intervention }\end{array}$ \\
\hline \multirow[t]{3}{*}{$\begin{array}{l}\text { 5. Levels of } \\
\text { action }\end{array}$} & $\begin{array}{l}\text { Macro: interventions implemented at an } \\
\text { organizational level (eg, corporate policies) }\end{array}$ \\
\hline & $\begin{array}{l}\text { Meso: interventions implemented at the level of } \\
\text { groups of workers (eg, team building) }\end{array}$ \\
\hline & $\begin{array}{l}\text { Micro: interventions targeting individual workers } \\
\text { (eg, education in work technique) }\end{array}$ \\
\hline $\begin{array}{l}\text { 6. Basic strategy } \\
\text { and method }\end{array}$ & $\begin{array}{l}\text { Implementation strategies: what was done and by } \\
\text { whom }\end{array}$ \\
\hline $\begin{array}{l}\text { 7. Explicit theory } \\
\text { or model }\end{array}$ & Explicit theory or model referred to (if any) \\
\hline $\begin{array}{l}\text { 8. Implicit } \\
\text { theory or } \\
\text { assumptions }\end{array}$ & $\begin{array}{l}\text { Tacit assumptions concerning the change process, } \\
\text { including its causes and effects. Extracted } \\
\text { primarily from the introduction and methods } \\
\text { sections of the article }\end{array}$ \\
\hline
\end{tabular}

interventions grounded on explicit and implicit theories, irrespective of the change theory, was not considered relevant.

\section{Results}

The 30 studies accepted for review $(17,57-85)$ are summarized in tables 2, 3 and 4, including their main characteristics according to the standardized protocol set out in table 1 above.

\section{Extracted explicit theories about the change process}

Thirteen of these publications referred to an explicit theory or model concerning the process of change (17, 57-68). Altogether, 12 different theories, named by the publications as cited below, were identified in the reviewed papers. Theories containing (elements of) participatory ergonomics were the most frequently referred to by five studies in total $(57,58,64,65,67)$. These were referred to as a cooperative inquiry model; reactive ergonomics intervention process or participatory theory/model. These theories have the common element of emphasizing that workers are experts in their own job and thus should be involved in the change process. Targets for change are, according to these theories, best identified by those involved in the job, and it is considered a key for successful implementation that solutions and implementation procedures be rooted among end users. Involving end users is also described as a core issue in interventions relying on other theories, for instance behavioral safety process theory and theory of change. Behavioral safety process theory, however, stresses a further dimension: the importance of communication and interaction for the change process to be successful. Behavioral safety process theory states that changes can happen when workers and specialists interact and that peers and a feedback system facilitate change (61). In Coles et al's (59) adoption of the theory of change, changes in awareness of risk factors related to health are assumed to result from participating in the intervention. All five of these change theories involving participation implicitly assume that the changes suggested and implemented by the participants have a positive effect on biomechanical or psychological risk factors.

Communication is also a major concern in diffusion of innovation and feedback-interaction theory. According to Eklöf et al (60), the assumption in the feedbackinteraction theory is that if workers are offered relevant information, their motivation to introduce work environment modifications will be reinforced. The diffusion of innovation theory focuses on the decision process in innovations (86). It originates from communication research and builds upon a five-step process of development: knowledge, persuasion, decision, implementation, and confirmation.

Only one study referred to social cognitive theory, which is a complex theory stating that personal factors as well as learned behavior and environmental determinates interact as important antecedents to change (87). Thus, personal, behavioral, and environmental factors all need to be considered in the implementation.

Finally, some theories represented in the articles had their main focus on technical change, such as the introduction of mechanical lifting equipment or alternative keyboards, while behavioral processes were addressed as a secondary focus. Three versions of these types of theories occurred in the reviewed studies: evidencebased model (88), ecological model of MSD (89), and learning curve theory (66). The evidence-based model emphasizes the use of research findings. Changes will, according to this theory, take place when workers or designers transfer their (increased) intellectual knowledge, for example about risk factors for work-related MSD, into practice. The ecological model of MSD originates from a study on office work (89) and claims that awareness of and experience with MSD influences psychosocial processes. The learning curve theory focuses on the individual process of change and the interaction between motor and cognitive learning.

Notably, all of the explicit theories used by the reviewed intervention studies were essentially based on assumptions about change processes at the level of individual workers, rather than at the level of organizational 
Table 2. Description of the 13 studies referring to an explicit theory of change, with reference to key items in the standardized examination protocol (see table 1). [NA=not available; MSD=musculoskeletal disorder.]

\begin{tabular}{|c|c|c|c|c|c|}
\hline $\begin{array}{l}\text { Author, } \\
\text { year of } \\
\text { publication }\end{array}$ & Title & $\begin{array}{l}\text { Action } \\
\text { level }\end{array}$ & $\begin{array}{l}\text { Number of subjects } \\
\text { (including controls) } \\
\text { Setting or occupation }\end{array}$ & $\begin{array}{l}\text { Explicit theory of } \\
\text { change }\end{array}$ & $\begin{array}{l}\text { Strategy for implementation / } \\
\text { Evidence of theory being applied }\end{array}$ \\
\hline $\begin{array}{l}\text { Burgess- } \\
\text { Limerick } \\
\text { et al, } 2007 \\
\text { (57) }\end{array}$ & $\begin{array}{l}\text { Implementation of the } \\
\text { Participative Ergonomics for } \\
\text { Manual tasks (PerforM) } \\
\text { program at } 4 \text { Australian }\end{array}$ & $\begin{array}{l}\text { Meso } \\
\text { Macro }\end{array}$ & $\begin{array}{l}\mathrm{N}=\mathrm{NA} \\
\text { Management and coal } \\
\text { mine workers / team } \\
\text { of workers from } 4\end{array}$ & $\begin{array}{l}\text { Participatory } \\
\text { ergonomics }\end{array}$ & $\begin{array}{l}\text { Training staff in risk management of manual } \\
\text { handling tasks through workshops and } \\
\text { participation in reducing risks. }\end{array}$ \\
\hline
\end{tabular}

$\begin{array}{ll} & \text { underground coal mines } \\ \text { Carayon } & \text { Teamwork and musculoskeleta } \\ \text { et al, 2006 } & \text { health in the context of work } \\ \text { (58) } & \text { organization interventions in }\end{array}$ office and computer work

Cole et al, Reducing musculoskeletal

2006 (59) burden through ergonomic program implementation at a large newspaper

Eklöf et al, Feedback of workplace data to

2004 (60) individual workers, workgroups or supervisors as a way to stimulate working environment activity: a cluster randomized controlled study

Faucett Rest break interventions in

et al, stooped-work tasks

2005 (17)

Meso

Macro sites

$\mathrm{N}=83$

A large public sector organization

Meso $\quad \mathrm{N}=433$

Newspaper

employees

Micro $\quad \mathrm{N}=\mathrm{NA}$

Meso 36 workgroups from 9 organizations. White-coller computer workers

Micro N=66

Meso Field workers

Macro

Gravina The effects of workstation et al, changes and behavioral

2007 (61) interventions on safe typing posture in an office

Greene Effects of an active ergonomics et al, training program on risk

2005 (62) exposure, worker beliefs, and symptoms in computer users

Gutric et al, A patient lifting intervention for 2004 (63) preventing the work-related injuries of nurses

Hess et al, A participatory ergonomics 2004 (64) intervention to reduce risk factors for low-back disorders among concrete labors

Laing et al, Effectiveness of a participa-

2007 (65) tory ergonomics intervention in improving communication and psychosocial exposure

Reid et al, Learning curve analysis of a 2007 (66) patient lift device

Rivilis et al, Evaluation of a participatory 2006 (67) ergonomic intervention aimed at improving musculoskeletal health

Swanson A multivariate evaluation of an et al, 2006 office ergonomic intervention (68) using longitudinal data

Micro $\quad \mathrm{N}=5$

Meso Library employees

Meso $\quad \mathrm{N}=87$ Computer users

Micro $\mathrm{N}=\mathrm{NA}$

Meso Orthopedic and

Macro neurology hospital staff

Micro $\quad \mathrm{N}=10$

Meso Laborers

Micro $\mathrm{N}=\mathrm{NA}$

Meso Manufacturing

Macro factory staff

Micro

$\mathrm{N}=18$

Occupation or settin not described.

Micro $\quad \mathrm{N}=122$

Meso Workers in courier company

Micro $\quad \mathrm{N}=189$

Employees insurance company
Participatory ergonomics

Theory of change

Feedback interaction theory

Feedback and discussion of ergon
chosocial work environment data
during one session with individua during one session with individuals, groups and supervisors.

Diffusion of innovation

Behavioral safety process

Social cognitive theory

Team building. Increased responsibility given to teams, including involving team members in decision-making. Weekly staff meeting for general communication and increased team skills in eg, stress reduction. Implementation of a questionnaire tool box addressing work conditions.

Ergonomics training activities focusing on repetitive tasks: workstation assessment.

Implementation of minimum 5 additional rest breaks every hour. Workers-management ergonomics committee. Workers and managers 8-10 hour training in ergonomics. Participation in the process of hazard identification.

Workstation adjustments and behavioral interventions: safe techniques/postures, peer observations and self-monitoring, visual feedback.

6-hour ergonomics training program at workstation addressing risk factors, symptoms, worker beliefs, intervention, skill development, workstation analysis.

Evidence-based Evidence-based process in a lifting intervention: practice lifting teams, lifting equipment, back school.

Cooperative inquiry model

Implementation of new ergonomic tool.

Researcher and participants agree on an area of inquiry and collaborate in selecting tools or work practice. Includes focus groups, adds to workers' education, builds knowledge.

Reactive ergonomics intervention

process; ergonomics program implementation blueprint

Learning curve theory

Ergonomics change team. Participatory change process design: newsletter distributed to workforce to communicate information and change process, ergonomic bulletin board, ergonomic suggestion box, presentations at shift meetings, ergonomic committee meetings, workstation adjustments, 1-minute surveys - follow up.

Apply standard learning curve analysis to individuals using a new patient lift. Two different training protocols: cognitive and motor training.

Participation model Ergonomic change team. Four training sessions and blueprint on basic ergonomic principles; identification of workplace risks and corrective actions. Tools to perform ergonomic assessment and measurement: identification-assessment-solution proposal-solution testing.

An alternative keyboard provided to half of the participants; others continued using conventional keyboard. Investigation of pathways between physical and organizational/psychosocial factors and MSD. 
structure. Participatory ergonomics theories can be viewed both as a theory of individual action and an idea of how to accomplish changes in the way work is organized. Nevertheless, in the reviewed articles, the implementation of participatory ergonomics mainly focused on individuals at work.

\section{Intervention strategies and implicit assumptions concerning change}

Of the 30 reviewed articles, 17 (69-85) did not present any explicit theory on change processes. In these cases, we had to use the description of the intervention strategies as a tacit source of information about the ideas behind the intervention. In table 3 , these implicit assumptions concerning change are characterized by 12 basic ideas. We could in turn, organize these ideas into four strategic categories. The first and most common category was "strategies targeting the individual" (ie, interventions comprising individual training, skill improvements, and education such as working technique and risk-reducing behaviors). The second category was "strategies focusing on the work environment", for instance workstation adjustments, new equipment, or ergonomic tools. The third category comprised "strategies emphasizing the process of change that happen when people interact", such as team building, participatory ergonomics, peer education, training by trainers, and different communicative strategies, for instance, suggestion boxes, newsletters, general information, or regular meetings. The fourth category was "structural/ organizational strategies"; that is interventions relying on organized rest breaks, establishment of ergonomic committees, or changed company policies. The most common intervention strategies in the 17 implicit studies were training or education, followed by workstation assessments and adjustments.

\section{Intervention strategies and theory of change}

The theoretical positions of the 30 reviewed interventions were identified in the quadrant model suggested by Wijk (11). This model illustrates the extent to which authors argue for the pedagogical ideas conveyed in their texts and not simply take them for granted. Thirteen articles $(17,57-68)$ reported interventions with reference to an explicit theory of change, and also established the change strategy firmly on basis of that theory; these articles were thus assigned to the upper right quadrant (figure 1). For example, a study might explicitly claim to base its intervention on the theory of diffusion of innovation (90) and consequently employ a strategy involving participants in the change process, relying on extensive communication as a core element. One article, referring to a specific theory but not report- ing any links between this theory and the implemented strategy, was assigned to the upper left quadrant (59). Those 17 articles exhibiting an implicit theory were assigned to one of the two lower quadrants. The lower right quadrant contains studies that refer to research results from previous studies or implicitly reflect upon the process of change that underpin the intervention (69-71, 74, 76-80, 82-85). As an example, Bohr (70) stated that "a problem-solving approach was used to recognize ergonomic problems" but did not explicitly refer to a theory of change. Finally, we allocated 4 studies out of $30(72,73,75,81)$ to the lower left corner as they expressed an implicit theory of change, but did not refer to any previous research concerning how to implement the change process.

\section{Discussion}

In this collection of 30 ergonomics intervention studies, less than half referred to an explicit theory of change, and 5 studies appeared not to have employed a distinct intervention strategy based on any established theory or model of change (figure 1). This striking finding, illustrating the general shortage of interventions rooted in theory, was further corroborated by the fact that we found only 30 studies in total problematizing the process of change in ergonomics interventions, despite our broad search process in databases covering about 15000 scientific journals, and despite the fact that both our own literature search and previous reviews of other aspects of ergonomics intervention have shown that the intervention literature is abundant. Since a sound theory on the intended change process is a crucial element of any informed intervention (eg, 91) this result strongly suggests a severe shortcome of many ergonomics intervention initiatives, or at least a serious lack of emphasis on reporting important factors and conditions associated with their design and implementation. Similar conclusions have been stated in other reviews of occupational interventions (eg, 92).

The most frequently used strategies in the 30 reviewed intervention studies consisted of training or education of the individual worker, accompanied by an opportunity to adjust workstations or tools. This suggests that a dominating theory is that providing people with better knowledge or skills, or better technical work conditions, will result in a positive change. On the whole, the individual - alone or in interaction with colleagues - is a central target in the reviewed ergonomic interventions. Organizational "macro-level" changes (table 1) occurred less frequently, and they were always combined with "meso" initiatives targeting groups of individuals. Notably, the distinction between the micro-, 
Table 3. Description of the 17 studies relying on an implicit theory of change, with reference to key items in the standardized examination protocol (see table 1). [VDU=video display unit]

\begin{tabular}{|c|c|c|c|c|c|}
\hline $\begin{array}{l}\text { Author, } \\
\text { year of } \\
\text { publication }\end{array}$ & Title & $\begin{array}{l}\text { Action } \\
\text { level }\end{array}$ & $\begin{array}{l}\text { Number of subjects } \\
\text { (including controls) } \\
\text { Setting or } \\
\text { occupation }\end{array}$ & $\begin{array}{l}\text { Explicit } \\
\text { theory } \\
\text { of } \\
\text { change }\end{array}$ & $\begin{array}{l}\text { Implicit assumptions concerning change, based on } \\
\text { intervention strategy (implicit theory of change) }\end{array}$ \\
\hline $\begin{array}{l}\text { Aarås et al, } \\
2001(69)\end{array}$ & $\begin{array}{l}\text { Musculoskeletal, visual } \\
\text { and psychosocial stress } \\
\text { in VDU operators before } \\
\text { and after multidisci- } \\
\text { plinary ergonomic inter- } \\
\text { ventions. A 6-year pro- } \\
\text { spective study, Part II }\end{array}$ & $\begin{array}{l}\text { Micro } \\
\text { Meso }\end{array}$ & $\begin{array}{l}\mathrm{N}=150 \text { males } \\
\text { VDU operators, } \\
\text { software } \\
\text { engineering }\end{array}$ & No & $\begin{array}{l}\text { Physical environment affects body. } \\
\text { Changed behavior through new techniques or aids. } \\
\text { Learning by doing (practice is required to adhere change). }\end{array}$ \\
\hline $\begin{array}{l}\text { Bohr, } \\
2000(70)\end{array}$ & $\begin{array}{l}\text { Efficacy of ergonomic } \\
\text { education }\end{array}$ & Meso & $\begin{array}{l}\mathrm{N}=154 \\
\text { Employees who } \\
\text { used computers at } \\
\text { least 5-hours per } \\
\text { work day }\end{array}$ & No & $\begin{array}{l}\text { Physical environment affects body . } \\
\text { Knowledge and/or information improves health through changed behavior. } \\
\text { Problem-based learning contributes to change. } \\
\text { Participatory education/ergonomics (employees are experts in their field). }\end{array}$ \\
\hline $\begin{array}{l}\text { Collins } \\
\text { et al, } 2004 \\
(71)\end{array}$ & $\begin{array}{l}\text { An evaluation of a "best } \\
\text { practice" musculoskele- } \\
\text { tal injury prevention pro- } \\
\text { gram in nursing homes }\end{array}$ & $\begin{array}{l}\text { Meso } \\
\text { Macro }\end{array}$ & $\begin{array}{l}\mathrm{N}=1728 \\
\text { Nursing staff in six } \\
\text { nursing homes }\end{array}$ & No & $\begin{array}{l}\text { Physical environment affects body. } \\
\text { Changed behavior through new techniques or aids. } \\
\text { Knowledge and/or information improves health through changed behavior. } \\
\text { Policies affect how employees act. }\end{array}$ \\
\hline $\begin{array}{l}\text { Engkvist, } \\
2006(72)\end{array}$ & $\begin{array}{l}\text { Evaluation of an } \\
\text { intervention compris- } \\
\text { ing a no-lifting policy in } \\
\text { Australian hospitals }\end{array}$ & $\begin{array}{l}\text { Meso } \\
\text { Macro }\end{array}$ & $\begin{array}{l}\mathrm{N}=587 \\
\text { Hospital staff }\end{array}$ & No & $\begin{array}{l}\text { Learning by doing (practice is required to trigger change). } \\
\text { Knowledge and/or information improves health through changed behavior. } \\
\text { Problem-based learning contributes to change. } \\
\text { Role models inspire to healthy behaviors. } \\
\text { Policies affect how employees act. }\end{array}$ \\
\hline $\begin{array}{l}\text { Fanello et } \\
\text { al, } 2002 \\
(73)\end{array}$ & $\begin{array}{l}\text { Evaluation of a training } \\
\text { program for the pre- } \\
\text { vention of lower-back } \\
\text { pain among hospital } \\
\text { employees }\end{array}$ & Meso & $\begin{array}{l}\mathrm{N}=136 \\
\text { Nurses, nursing } \\
\text { assistants, clean- } \\
\text { ing staff }\end{array}$ & No & $\begin{array}{l}\text { Physical environment affect body. } \\
\text { Learning by doing (practice is required to trigger change).Knowledge and/ } \\
\text { or information improves health through changed behavior. } \\
\text { Participatory education/ergonomics (employees are experts in their field). }\end{array}$ \\
\hline $\begin{array}{l}\text { Galinsky } \\
\text { et al, } \\
2000(74)\end{array}$ & $\begin{array}{l}\text { A field study of supple- } \\
\text { mentary rest breaks for } \\
\text { data-entry operators }\end{array}$ & Micro & $\begin{array}{l}\mathrm{N}=42 \\
\text { Data-entry } \\
\text { operators }\end{array}$ & No & $\begin{array}{l}\text { Physical environment affects body. } \\
\text { Organizational structure affect health. }\end{array}$ \\
\hline $\begin{array}{l}\text { Gatty, } \\
2004(75)\end{array}$ & $\begin{array}{l}\text { A comprehensive work } \\
\text { injury prevention pro- } \\
\text { gram with clerical and } \\
\text { office workers: Phase II }\end{array}$ & Micro & $\begin{array}{l}\mathrm{N}=16 \\
\text { Clerical, office } \\
\text { workers }\end{array}$ & No & $\begin{array}{l}\text { Physical environment affects body. } \\
\text { Changed behavior through new techniques or aids. } \\
\text { Knowledge and/or information improves health through changed behavior. } \\
\text { Organizational structure affect health (task modification). }\end{array}$ \\
\hline $\begin{array}{l}\text { Goodman } \\
\text { et al, } 2005 \\
(76)\end{array}$ & $\begin{array}{l}\text { Effectiveness of comput- } \\
\text { er ergonomics interven- } \\
\text { tions for an engineering } \\
\text { company: a program } \\
\text { evaluation }\end{array}$ & Micro & $\begin{array}{l}\mathrm{N}=13 \\
\text { Computer users } \\
\text { engineers }\end{array}$ & No & $\begin{array}{l}\text { Physical environment affects body. } \\
\text { Changed behavior through new techniques or aids. } \\
\text { Knowledge and/or information improves health through changed behavior. } \\
\text { Participatory education/ergonomics (employees are experts in their field). }\end{array}$ \\
\hline $\begin{array}{l}\text { Hartvigsen } \\
\text { et al, } 2005 \\
\text { (77) }\end{array}$ & $\begin{array}{l}\text { Intensive education } \\
\text { combined with low-tech } \\
\text { ergonomic intervention } \\
\text { does not prevent low } \\
\text { back pain in nurses }\end{array}$ & $\begin{array}{l}\text { Micro } \\
\text { Meso }\end{array}$ & $\begin{array}{l}\mathrm{N}=345 \\
\text { Home care nurses } \\
\text { and nurses'aids }\end{array}$ & No & $\begin{array}{l}\text { Knowledge and/or information improve health through changed behavior. } \\
\text { Role models at work inspire colleagues. } \\
\text { Organized communication (eg, feedback systems or meetings) increase } \\
\text { awareness of risk and/or health issues. }\end{array}$ \\
\hline $\begin{array}{l}\text { Hodge et al, } \\
2002(78)\end{array}$ & $\begin{array}{l}\text { An occupational health } \\
\text { nursing education } \\
\text { program }\end{array}$ & Meso & $\begin{array}{l}\mathrm{N}=84 \\
\text { Nursing students }\end{array}$ & No & $\begin{array}{l}\text { Knowledge and/or information improves health through changed behavior. } \\
\text { Organized communication (eg, feedback systems or meetings) increase } \\
\text { awareness of risk and/or health issues. }\end{array}$ \\
\hline $\begin{array}{l}\text { Ketola et al, } \\
2002(79)\end{array}$ & $\begin{array}{l}\text { Effects of ergonomic } \\
\text { intervention in work with } \\
\text { video display units }\end{array}$ & $\begin{array}{l}\text { Micro } \\
\text { Meso }\end{array}$ & $\begin{array}{l}\mathrm{N}=124 \\
\text { VDU operators }\end{array}$ & No & $\begin{array}{l}\text { Physical environment affects body. } \\
\text { Changed behavior through new techniques or aids. } \\
\text { Learning by doing (practice is required to trigger change).Knowledge and/ } \\
\text { or information improves health through changed behavior. } \\
\text { Participatory education/ergonomics (employees are experts in their field). } \\
\text { Organized communication (eg, feedback systems or meetings increase } \\
\text { awareness of risk and/or health issues). } \\
\text { Organizational structure affects health. }\end{array}$ \\
\hline $\begin{array}{l}\text { Morken et } \\
\text { al, } 2002 \\
\text { (80) }\end{array}$ & $\begin{array}{l}\text { Effects of a training pro- } \\
\text { gram to improve muscu- } \\
\text { loskeletal health among } \\
\text { industrial workers - ef- } \\
\text { fects of supervisors role } \\
\text { in the intervention }\end{array}$ & Meso & $\begin{array}{l}\mathrm{N}=5654 \text { at base- } \\
\text { line, } 3321 \text { matched } \\
\text { participants } \\
\text { Operators in alumi- } \\
\text { num industry }\end{array}$ & No & $\begin{array}{l}\text { Changed behavior through new techniques or aids } \\
\text { Learning by doing (Practice is required to trigger change) } \\
\text { Participatory education/ergonomics (Employees are experts in their field) } \\
\text { Organized communication e.g. feedback systems or meetings increase } \\
\text { awareness of risk and/or health issues } \\
\text { Psychosocial support at work contribute to improved health }\end{array}$ \\
\hline
\end{tabular}


Table 3. Continued

\begin{tabular}{|c|c|c|c|c|c|}
\hline $\begin{array}{l}\text { Author, } \\
\text { year of } \\
\text { publication }\end{array}$ & Title & $\begin{array}{l}\text { Action } \\
\text { levels }\end{array}$ & $\begin{array}{l}\text { Number of subjects } \\
\text { (including controls) } \\
\text { Setting or } \\
\text { occupation }\end{array}$ & $\begin{array}{l}\text { Explicit } \\
\text { theory } \\
\text { of } \\
\text { change }\end{array}$ & $\begin{array}{l}\text { Implicit assumptions concerning change, based on intervention strategy } \\
\text { (implicit theory of change) }\end{array}$ \\
\hline $\begin{array}{l}\text { Nag et al, } \\
2007(81)\end{array}$ & $\begin{array}{l}\text { Hazards and health com- } \\
\text { plaints associated with } \\
\text { fish processing activities } \\
\text { in India - evaluation of a } \\
\text { low-cost intervention }\end{array}$ & Micro & $\begin{array}{l}\mathrm{N}=185 \\
\text { Women in fish } \\
\text { processing works }\end{array}$ & No & Changed behavior through new techniques or aids. \\
\hline $\begin{array}{l}\text { Nelson et } \\
\text { al, } 2006 \\
(82)\end{array}$ & $\begin{array}{l}\text { Development and evalu- } \\
\text { ation of a multifaceted } \\
\text { ergonomics program to } \\
\text { prevent injuries associat- } \\
\text { ed with patient handling } \\
\text { tasks }\end{array}$ & $\begin{array}{l}\text { Meso } \\
\text { Macro }\end{array}$ & $\begin{array}{l}\mathrm{N}=825 \\
\text { Nursing staff }\end{array}$ & No & $\begin{array}{l}\text { Changed behavior through new techniques or aids. } \\
\text { Knowledge and/or information improves health through changed behavior. } \\
\text { Role models at work inspire colleagues. } \\
\text { Policies affect how employees act. } \\
\text { Changes requires improvements in organizational structure as well as for } \\
\text { individuals, no single solution lead to change. }\end{array}$ \\
\hline $\begin{array}{l}\text { Peper et al, } \\
2004 \text { (83) }\end{array}$ & $\begin{array}{l}\text { Group training with } \\
\text { healthy computing } \\
\text { practices to prevent re- } \\
\text { petitive strain injury } \\
\text { (RSI): a preliminary } \\
\text { study }\end{array}$ & Meso & $\begin{array}{l}\mathrm{N}=28 \\
\text { Employees at } \\
\text { university }\end{array}$ & No & $\begin{array}{l}\text { Changed behavior through new techniques or aids. } \\
\text { Learning by doing (practice is required to trigger change). } \\
\text { Knowledge and/or information improves health through changed behavior. } \\
\text { Role models at work inspire colleagues. } \\
\text { Organized communication (eg, feedback systems or meetings) increase } \\
\text { awareness of risk and/or health issues. } \\
\text { Psychosocial support at work contribute to improved health. } \\
\text { Changes requires improvements in organizational structure as well as for } \\
\text { individuals, no single solution lead to change. }\end{array}$ \\
\hline $\begin{array}{l}\text { Pillastrini } \\
\text { et al } 2007 \\
\text { (84) }\end{array}$ & $\begin{array}{l}\text { Evaluation of two pre- } \\
\text { ventive interventions for } \\
\text { reducing musculoskel- } \\
\text { etal complaints in ppera- } \\
\text { tors of video display } \\
\text { terminals }\end{array}$ & Micro & $\begin{array}{l}\mathrm{N}=200 \\
\text { Video display } \\
\text { terminal operators }\end{array}$ & No & $\begin{array}{l}\text { Physical environment affects body. } \\
\text { Changed behavior through new techniques or aids. } \\
\text { Learning by doing (practice is required to trigger change). } \\
\text { Knowledge and/or information improves health through changed behavior. } \\
\text { Organized communication (eg, feedback systems or meetings) increase } \\
\text { awareness of risk and/or health issues. }\end{array}$ \\
\hline $\begin{array}{l}\text { Smith et al, } \\
2003(85)\end{array}$ & $\begin{array}{l}\text { Do ergonomics improve- } \\
\text { ments' increase comput- } \\
\text { er workers' productivity: } \\
\text { an intervention study in } \\
\text { a call centre }\end{array}$ & Micro & $\begin{array}{l}\mathrm{N}=72 \\
(\text { control } \mathrm{N}=370) \\
\text { call centre control } \\
\text { group }\end{array}$ & No & $\begin{array}{l}\text { Physical environment affects body. } \\
\text { Changed behavior through new techniques or aids. } \\
\text { Learning by doing (practice is required to trigger change). }\end{array}$ \\
\hline
\end{tabular}

meso- and macro-levels is somewhat artificial. An intervention on the individual level leading to, for example, less absenteeism, will probably result in outcomes on an organizational level, such as cost savings and increased productivity for the company $(31,32)$. Still, several "macro" organizational theories or models that have not been used in any of the reviewed ergonomics interventions should have a potential in an ergonomics context (93-95). This would be in line with the suggestions of several researchers to reconsider the role of the ergonomist, from focusing on individual workers to acting at a higher organizational level (eg, 5, 6). We believe the dominance of interventions targeting individuals or groups to be representative of scientifically studied ergonomics interventions, since our search included even reference databases containing journals addressing management science and organizational issues. This belief is supported by similar observations in previous reviews of ergonomics interventions and their effects $(42,46)$. The dominance may reflect a bias of both intervention ideas and selection of research issues among ergonomists towards a focus on the individual rather than the organization. Natural interventions, initiated and driven by companies, may to a much larger extent be directed towards issues in production and management (28).
The reviewed articles give the impression that intervention strategies based on participation have attained a dominant position in ergonomics. Typically, participation is externalized in programs where employees identify ergonomics issues that can be improved and also participate in the process of changing the work conditions. Some may argue that participatory theory is a method or model rather than a theory, but since the reviewed studies use the term "theory" we also adopted that terminology. Backman \& Kyngäs (12) describe the distinction between theory and model as follows: "In the scientific sense, a model may be used to define or describe something and to specify relationships and processes, while a theory is a systematically related set of statements, including law-like generations, which is empirically testable" (p148). Irrespective of any formal distinction between theory and model, both suggest causal relationships.

We believe, in keeping with commonly accepted convictions that an intervention will have a better chance of success if it carefully adheres to a viable theory for change and follows a consequent strategy based on this theory, designed with due consideration to contextual factors in the organization $(7,92)$. We could not, however, verify this belief on basis of the 30 


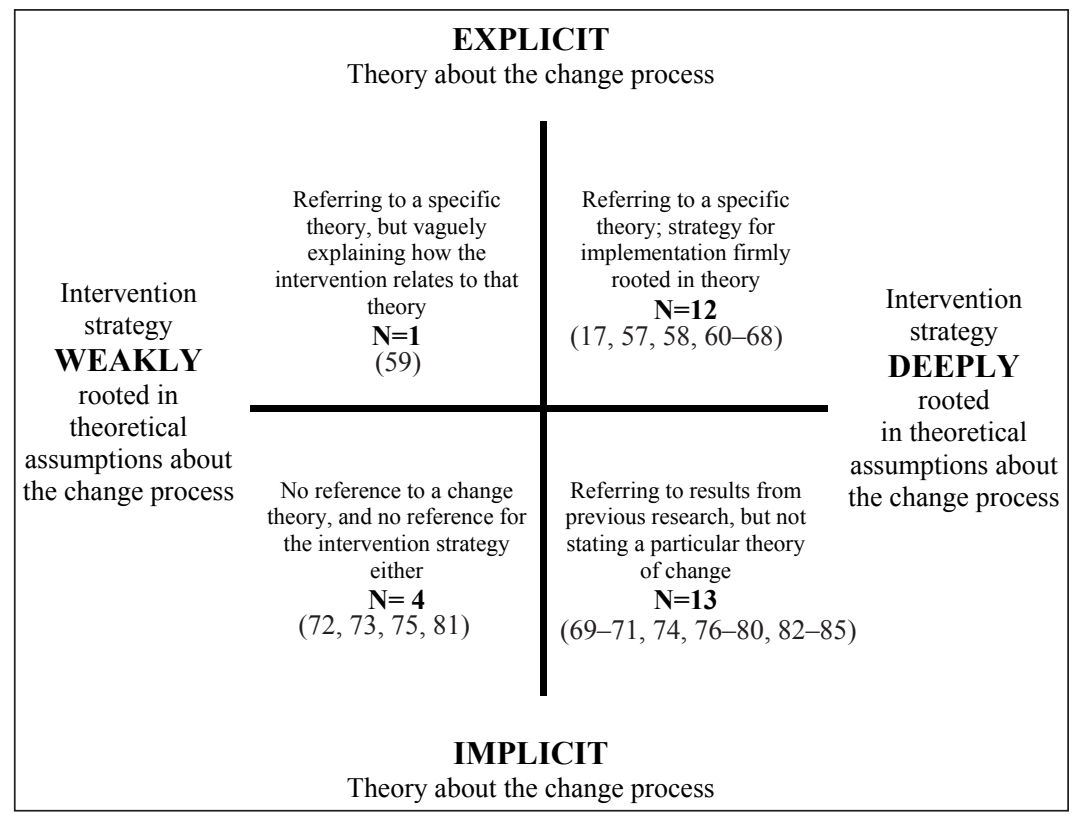

Figure 1. Classification of reviewed studies according to whether they are based on an explicit or implicit theory, and whether the intervention strategy is deeply or weakly rooted in this theory; model based on Wijk (11). Numbers in brackets refer to the reference list. reviewed studies. All reviewed studies but one reported that the intervention was, in some respect, successful, but none discussed this result in relation to a theory of change or the implemented strategy. Furthermore, the generally successful appearance of the interventions may be a result of reporting and publication bias, as noted in other intervention reviews $(32,46$, 96), and thus not representative of the benefits of one theory above another. A possible association between the implemented theory of change and the positive or negative outcome of an intervention is an issue that deserves attention in future research. In order to fully appreciate such associations, reports are needed also on unsuccessful interventions.

Some intervention studies outside our review do, however, illustrate that interventions may fail if they do not duly appreciate that strategies should follow a feasible model, adjusted to prevailing work conditions. In a study on office workers by Henning et al (97), frequent micro-breaks were disliked in one company because they interfered with normal work, and the intervention did not reach its intended result. However, it had a positive effect in another company where the break scheme complied with work routines. Christmansson et al (98) reported an aversion among assembly workers to a job enlargement intervention because they were not properly introduced to their new tasks. An illustration of the fact that better knowledge may not necessarily lead to improvements was reported in a study of slaughterhouse meatpackers (99). Inspite of the workers having received extensive education on the benefits of rest breaks, less than $5 \%$ of an additional time allowance for breaks were utilized. Apparently any possible wish to use this new competence was drowned out by other strong drivers of behavior.

The different stakeholder roles in initiating, planning, implementing, and evaluating change is an important aspect of ergonomics interventions and likely to have a major influence on the feasibility, acceptance, and sustainability of the intervention $(6,28,100)$. While this is also a core aspect in most theories of change, too little information was available in the reviewed studies to allow for an analysis, and so we could not identify key stakeholders.

This review includes qualitative interpretations of the methods and results as reported by the analyzed studies, which do not necessarily reflect "reality" in terms of how the intervention was, in fact, planned and implemented. Also, the change process might well have looked different from the perspective of others involved, besides the researchers. The methods and introduction sections, including aims, of the reviewed intervention studies differed widely with respect to their extent and clarity, and the authors put their emphasis on different aspects of the intervention. Some articles extensively described study design, data collection, and the core intervention procedures, while others did not. Thus, direct comparisons across studies of the ideas underlying the interventions were difficult. Also, important strategies and theories of specific interventions may have been left unreported by the authors. In several cases, this also led to problems defining the level (ie, macro, meso, or micro) at which the intervention was conducted, let alone important stakeholders, as commented above. 


\section{Concluding remarks}

Ergonomics interventions will probably have a greater chance of reaching desired effects if they are designed on the basis of a sound theory of change adapted to the prevailing conditions in the organization and implemented accordingly (91). Given this credo, it is surprising that only 30 studies among an extensive literature on ergonomics interventions reported any interpretable theory of change and that less than half of these studies referred to an explicit theory of change and realized the intervention with this theory in mind. Also, the emphasis on interventions focusing on individuals rather than organizations was striking. We recommend that ergonomics interventions be designed with a better awareness of the underlying assumptions about change processes, and that the implementation strategy should be firmly rooted in an appropriate theory, including decisions about when, why, for how long, and with whom the intervention should take place. This could probably lead to a more effective implementation of each specific intervention, but eventually also to the identification of theories and strategies that promote or restrict a successful intervention. A prerequisite for this to happen, however, is that the theory of change and the subsequent implementation is sufficiently documented. We hope that the present paper can contribute to this development by giving an empirical starting point for further progress.

\section{Acknowledgements}

Hasse Nordlöf is gratefully acknowledged for his invaluable contribution in analyzing the identified intervention studies. We also wish to thank Thomas Karlsson for participating in the interpretation of tacit assumptions and Laura Punnett and Göran Hägg for critically reviewing previous versions of the manuscript.

\section{References}

1. National Research Council. Musculoskeletal Disorders and the Workplace. Washington DC: National Academies Press; 2001.

2. Punnett L, Wegman, DH. Work-related musculoskeletal disorders: the epidemiologic evidence and the debate. J Electromyogr Kinesiol. 2004;14:13-23. doi:10.1016/j. jelekin.2003.09.015.

3. European Agency for Safety and Health at Work. Work-related musculoskeletal disorders: Prevention report. Luxembourg: European Agency for Safety and Health at Work; 2008.

4. OECD Directorate for Employment Labour and Social Affairs. Sickness, Disability and Work: Breaking the Barriers. Paris:
OECD; 2009.

5. Dul J, Neumann WP. Ergonomics contributions to company strategies. Appl Ergon. 2009;40(4):745-52.doi:10.1016/j. apergo.2008.07.001.

6. Jensen PL. Human factors and ergonomics in the planning of production. Int J Ind Ergon. 2002;29(3):121-31. doi:10.1016/ S0169-8141(01)00056-7.

7. National Cancer Institute. Theory at a glance: a guide for health promotion practices (Second Edition). Bethesda MD: US Department of Health and Human Services. National Institutes of Health; 2005.

8. Danermark B. Explaining society : critical realism in the social sciences. London: Routledge; 2002.

9. Hellevik O. Introduction to Causal Analysis. London: George Allen \& Unwin; (1988. Oslo: Norwegian University Press); 1984.

10. French J, Adams L. From analysis to synthesis. Theories of health education. Health Educ J. 1986;45(2):71-4.

11. Wijk K. Planning and implementing health interventions. Extrapolated theories of health education and constructed determinants of risk-taking. (University dissertation from Acta Universitatis Upsaliensis) Uppsala: Uppsala University; 2003. ISSN:0347-1314.

12. Backman K, Kyngäs HA. Challenges of the grounded theory approach to a novice researcher. Nurs Health Sci. 1999;1(3):147-53. doi:10.1046/j.1442-2018.1999.00019.x.

13. Sandelowski M. Theory unmasked: The uses and guises of theory in qualitative research. Res Nurs Health. 1993;16(3):213-8. doi:10.1002/nur.4770160308.

14. Keyserling WM. Workplace risk factors and occupational musculoskeletal disorders, part 2: A review of biomechanical and psychophysical research on risk factors associated with upper extremity disorders. Am Ind Hyg Assoc J. 2000;61(2):231-43. doi:10.1080/15298660008984532.

15. van der Windt DlAWM, Thomas E, Pope DP, de Winter AF, Macfarlane GJ, Bouter LM, Silman AJ. Occupational risk factors for shoulder pain: a systematic review. Occup Environ Med. 2000;57(7):433-42.

16. Ariens GA, van Mechelen W, Bongers PM, Bouter LM, van der Wal G. Physical risk factors for neck pain. Scand J Work Environ Health. 2000;26(1):7-19.

17. Faucett J. Integrating 'psychosocial' factors into a theoretical model for work-related musculoskeletal disorders. Theor Issues Ergon Sci. 2005;6(6):531-50. doi:10.1080/14639220 512331335142 .

18. Bongers PM, Ijmker S, van den Heuvel S, Blatter BM. Epidemiology of work related neck and upper limb problems: psychosocial and personal risk factors (part I) and effective interventions from a bio behavioural perspective (part II). J Occup Rehabil. 2006 Sep;16(3):279-302. doi:10.1007/ s10926-006-9044-1.

19. Mathiassen SE, Winkel J, Hagg GM. Normalization of surface EMG amplitude from the upper trapezius muscle in ergonomic studies - A review. J Electromyogr Kinesiol. 1995;5(4):197226. doi:10.1016/1050-6411(94)00014-X

20. van der Beek AJ, Frings-Dresen MH. Assessment of 
mechanical exposure in ergonomic epidemiology. Occup Environ Med. 1998 May 1998;55(5):291-9.

21. BurdorfA, van der Beek A. Exposure assessment strategies for work-related risk factors for musculoskeletal disorders. Scand J Work Environ Health. 1999;25 suppl 4:25-30.

22. David GC. Ergonomic methods for assessing exposure to risk factors for work-related musculoskeletal disorders. Occup Med. 2005;55(3):190-9.

23. Takala EP, Pehkonen I, Forsman M, Hansson GA, Mathiassen SE, Neumann WP, Sjogaard G, Veiersted KB, Westgaard RH, Winkel J. Systematic evaluation of observational methods assessing biomechanical exposures at work. Scand J Work Environ Health. 2010;36(1):3-24.

24. Karsh B-T. Theories of work-related musculoskeletal disorders: Implications for ergonomic interventions. Theoretical Issues in Ergonomics Science. 2006;7(1):71-88. doi: $10.1080 / 14639220512331335160$

25. Visser B, van Dieën JH. Pathophysiology of upper extremity muscle disorders. J Electromyogr Kinesiol. 2006 Feb;16(1):116. doi:10.1016/j.jelekin.2005.06.005.

26. van Oostrom S, Driessen, MT., De Vet, HC., Franche, RL., Schonstein, E., Loisel, P., van Mechelen, W., Anema, JR. Workplace interventions for preventing work disability. Cochrane Database Syst Rev. 2009;Apr 15(2):CD006955.

27. Driessen MT, Proper KI, van Tulder MW, Anema JR, Bongers PM, van der Beek AJ. The effectiveness of physical and organisational ergonomic interventions on low back pain and neck pain: a systematic review. Occup Environ Med. 2010;67(4):277-85. doi:10.1136/oem.2009.047548.

28. Westgaard RH, Winkel J. Occupational musculoskeletal and mental health: Significance of rationalization and opportunities to create sustainable production systems - A systematic review. Appl Ergon. 2011;42(2):261-96. doi:10.1016/j. apergo.2010.07.002.

29. Dinnes J, Loveman E, McIntyre L, Waugh N. The effectiveness of diagnostic tests for the assessment of shoulder pain due to soft tissue disorders: a systematic review. Health Technol Assess. 2003;7(29):iii, 1-166.

30. Haldeman S, Carroll L, Cassidy JD, Schubert J, Nygren Ãk. The Bone and Joint Decade 2000-2010 Task Force on Neck Pain and Its Associated Disorders: Executive Summary. Spine. 2008;33(4S):S5-S7. doi:10.1097/BRS.0b013e3181643f40.

31. Beevis D. Ergonomics--Costs and Benefits Revisited. Applied Ergonomics. 2003;34(5):491-6. doi:10.1016/S00036870(03)00068-1.

32. Goggins RW, Spielholz P, Nothstein GL. Estimating the effectiveness of ergonomics interventions through case studies: implications for predictive cost-benefit analysis. J Safety Res. 2008;39(3):339-44. doi:10.1016/j.jsr.2007.12.006.

33. Tompa E, Dolinschi R, de Oliveira C, Amick B, Irvin E. A Systematic Review of Workplace Ergonomic Interventions with Economic Analyses. J Occup Rehab. 2010;20(2):220-34. doi:10.1007/s10926-009-9210-3.

34. Wilkens PM. Preventing work-related musculoskeletal disorders in VDT users: A comprehensive health promotion program. Work. 2003;20(3):171-8.

35. Wasilewski RM, Mateo P, Sidorovsky P. Preventing workrelated musculoskeletal disorders within supermarket cashiers: An ergonomic training program based on the theoretical framework of the PRECEDE-PROCEED model. Work. 2007;28(1):23-31.

36. Rosenstock $\mathrm{L}$. The future of intervention research at NIOSH. Am J Ind Med. 1996 Apr;29(4):295-7. doi:10.1002/(SICI)10970274(199604)29:4<295::AID-AJIM3>3.0.CO;2-O.

37. Jarus T, Ratzon NZ. The implementation of motor learning principles in designing prevention programs at work. Work. 2005;24(2):171-82.

38. Waters T, Collins J, Galinsky T, Caruso C. NIOSH research efforts to prevent musculoskeletal disorders in the healthcare industry. Orthop Nurs 2006 Nov-Dec;25(6):380-9. doi:10.1097/00006416-200611000-00007

39. Roquelaure Y. Workplace intervention and musculoskeletal disorders: the need to develop research on implementation strategy. Occup Environ Med. 2008 January;65(1):4-5.

40. Rosecrance JC, Cook TM. The Use of Participatory Action Research and Ergonomics in the Prevention of WorkRelated Musculoskeletal Disorders in the Newspaper Industry. Appl Occup Environ Hyg. 2000;15(3):255- 62. doi:10.1080/104732200301575.

41. Denis D, St-Vincent M, Imbeau D, Jetté C, Nastasia I. Intervention practices in musculoskeletal disorder prevention: A critical literature review. Appl Ergon. 2008;39(1):1-14. doi:10.1016/j.apergo.2007.02.002.

42. Westgaard RH, Winkel J. Ergonomic intervention research for improved musculoskeletal health: A critical review. Int J Ind Ergon. 1997;20(6):463-500. doi:10.1016/S01698141(96)00076-5.

43. Whysall Z, Haslam C, Haslam R. A stage of change approach to reducing occupational ill health. Prev Med. 2006;43(5):4228. doi:10.1016/j.ypmed.2006.07.004.

44. Rivilis I, Van Eerd D, Cullen K, Cole DC, Irvin E, Tyson J, Mahood Q. Effectiveness of participatory ergonomic interventions on health outcomes: A systematic review. Appl Ergon. 2008;39(3):342-58. doi:10.1016/j. apergo.2007.08.006.

45. Brewer S, Eerd D, Amick Iii B, Irvin E, Daum K, Gerr F, Moore J, Cullen K, Rempel D. Workplace interventions to prevent musculoskeletal and visual symptoms and disorders among computer users: A systematic review. J Occup Rehab. 2006;16(3):317-50. doi:10.1007/s10926-006-9031-6.

46. Silverstein B, Clark R. Interventions to reduce workrelated musculoskeletal disorders. J Electromyogr kinesiol. 2004;14(1):135-52. doi:10.1016/j.jelekin.2003.09.023.

47. Haines H, Wilson, JR., Vink, P., \& Koningsveld, E. Validating a framework for participatory ergonomics (the PEF). Ergonomics. 2002;45:309-27. doi:10.1080/00140130210123516.

48. van der Molen HF, Sluiter JK, Hulshof CT, Vink P, van Duivenbooden C, Frings-Dresen MH. Conceptual framework for the implementation of interventions in the construction industry. Scand J Work Environ Health. 2005;31 Suppl 2:96-103. 
49. Higgins J, Green, S. (editors). Cochrane Handbook for Systematic Reviews of Interventions 4.2.6: The Cochrane Collaboration; 2006.

50. Amell T, Kumar S. Work-Related Musculoskeletal Disorders: Design as a Prevention Strategy. A Review. J Occup Rehab. 2001;11(4):255-65. doi:10.1023/A:1013344508217.

51. Aarås A, Horgen G, Ro O, Loken E, Mathiasen G, Bjorset HH, Larsen S, Thoresen M. The effect of an ergonomic intervention on musculoskeletal, psychosocial and visual strain of VDT data entry work: the Norwegian part of the international study. Int J Occup Saf Ergon. 2005;11(1):25-47.

52. Carayon P, Haims, M. C., \& Suh, H. Work organization interventions to prevent work-related musculoskeletal disorders in office and video display terminal work. Madison, WI: University of Wisconsin-Madison; 1998

53. Eklöf M, Hagberg M. Are simple feedback interventions involving workplace data associated with better working environment and health? A cluster randomized controlled study among Swedish VDU workers. Appl Ergon. 2006 Mar;37(2):201-10. doi:10.1016/j.apergo.2005.04.003.

54. Higgins J, Green, S. (editors). Cochrane Handbook for Systematic Reviews of Interventions Version 5.0.0 [updated February 2008]: The Cochrane Collaboration; 2008

55. Bos V, Van Kammen, J. Knowledge synthesis: a guide. The Hague and Woerden: ZonMw and NIGZ.2007.

56. Oldenburg BF, Sallis JF, Ffrench ML, Owen N. Health promotion research and the diffusion and institutionalization of interventions. Health Edu Res. 1999;14(1):121-30.

57. Burgess-Limerick R, Straker L, Pollock C, Dennis G, Leveritt $\mathrm{S}$, Johnson S. Implementation of the Participative Ergonomics for Manual tasks (PErforM) programme at four Australian underground coal mines. Int J Ind Ergon. 2007;37(2):145-55. doi:10.1016/j.ergon.2006.10.008.

58. Carayon P, Haims MC, Hoonakker PLT, Swanson NG. Teamwork and musculoskeletal health in the context of work organization interventions in office and computer work. Theor Issues Ergon Sci. 2006;7(1):39-69. doi:10.1080/146392205 12331335151

59. Cole D, Hogg-Johnson S, Manno M, Ibrahim S, Wells R, Ferrier S, The Worksite Upper Extremity Research G. Reducing musculoskeletal burden through ergonomic program implementation in a large newspaper. Int Arch Occup Environ Health. 2006;80(2):98-108. doi:10.1007/s00420-006-0107-6.

60. Eklöf M, Hagberg M, Toomingas A, Tornqvist EW. Feedback of workplace data to individual workers, workgroups or supervisors as a way to stimulate working environment activity: a cluster randomized controlled study. Int Arch Occup Environ Health. 2004 Oct;77(7):505-14. doi:10.1007/ s00420-004-0531-4.

61. Gravina N, Lindstrom-Hazel D, Austin J. The effects of workstation changes and behavioral interventions on safe typing postures in an office. Work. 2007;29(3):245-53.

62. Greene BL, DeJoy DM, Olejnik S. Effects of an active ergonomics training program on risk exposure, worker beliefs, and symptoms in computer users. Work. 2005;24(1):41-52.
63. Guthrie PF, Westphal L, Dahlman B, Berg M, Behnam K, Ferrell D. A patient lifting intervention for preventing the work-related injuries of nurses. Work. 2004;22(2):79-88.

64. Hess JA, Hecker S, Weinstein M, Lunger M. A participatory ergonomics intervention to reduce risk factors for low-back disorders in concrete laborers. Appl Ergon. 2004;35(5):42741. doi:10.1016/j.apergo.2004.04.003.

65. Laing AC, Cole DC, Theberge N, Wells RP, Kerr MS, Frazer MB. Effectiveness of a participatory ergonomics intervention in improving communication and psychosocial exposures. Ergonomics. 2007;50(7):1092-109. doi:10.1080/00140130701308708.

66. Reid SA, Mirka GA. Learning curve analysis of a patient liftassist device. Appl Ergon. 2007;38(6):765-71. doi:10.1016/j. apergo.2006.10.006

67. Rivilis I, Cole DC, Frazer MB, Kerr MS, Wells RP, Ibrahim $\mathrm{S}$. Evaluation of a participatory ergonomic intervention aimed at improving musculoskeletal health. Am J Ind Med. 2006;49(10):801-10. doi:10.1002/ajim.20382.

68. Swanson NG, Sauter SL. A multivariate evaluation of an office ergonomic intervention using longitudinal data. Theor Issues Ergon Sci. 2006;7(1):3-17.doi:10.1080/1463922051233133 5124.

69. Aarås A, Horgen G, Bjørset H-H, Ro O, Walsøe H. Musculoskeletal, visual and psychosocial stress in VDU operators before and after multidisciplinary ergonomic interventions. A 6 years prospective study--Part II. Appl Ergon. 2001;32(6):559-71. doi:10.1016/S0003-6870(01)00030-8.

70. Bohr PC. Efficacy of office ergonomics education. J Occup Rehab. 2000;10(4):243-55. doi:10.1023/A:1009464315358.

71. Collins JW, Wolf L, Bell J, Evanoff B. An evaluation of a "best practices" musculoskeletal injury prevention program in nursing homes. Inj Prev. 2004;10(4):206-11.

72. Engkvist I-L. Evaluation of an intervention comprising a No Lifting Policy in Australian hospitals. Appl Ergon. 2006;37(2):141-8. doi:10.1016/j.apergo.2005.05.008.

73. Fanello S, Jousset N, Roquelaure Y, Chotard-Frampas V, Delbos V. Evaluation of a training program for the prevention of lower back pain among hospital employees. Nurs Health Sci. 2002;4(1-2):51-4. doi:10.1046/j.1442-2018.2002.00098.x.

74. Galinsky TL, Swanson NG, Sauter SL, Hurrell JJ, Schleifer LM. A field study of supplementary rest breaks for dataentry operators. Ergonomics. [Article]. 2000;43(5):622-38. doi:10.1080/001401300184297.

75. Gatty CM. A comprehensive work injury prevention program with clerical and office workers: Phase II. Work. 2004;23(2):131-7.

76. Goodman G, Landis J, George C, McGuire S, Shorter C, Sieminski M, Wilson T. Effectiveness of computer ergonomics interventions for an engineering company: A program evaluation. Work. 2005;24(1):53-62.

77. Hartvigsen J, Lauritzen S, Lings S, Lauritzen T. Intensive education combined with low tech ergonomic intervention does not prevent low back pain in nurses. Occup Environ Med. 2005;62(1):13-7. 
78. Hodge BD, Ackerman S, Evans C, Erb T, Cook ML. An occupational health nursing education program. Relevance to nurses in nonoccupational practice settings. AAOHN J. 2002 Jun;50(6):257-61.

79. Ketola R, Toivonen R, Hakkanen M, Luukkonen R, Takala EP, Viikari-Juntura E. Effects of ergonomic intervention in work with video display units. Scand J Work Environ Health. 2002;28(1):18-24.

80. Morken T, Moen B, Riise T, Hauge SHV, Holien S, Langedrag A, Olson H-O, Pedersen S, Saue ILL, Seljebø GM, Thoppil $\mathrm{V}$. Effects of a training program to improve musculoskeletal health among industrial workers--effects of supervisors role in the intervention. Int J Ind Ergon. 2002;30(2):115-27. doi:10.1016/S0169-8141(02)00090-2.

81. Nag PK, Nag A. Hazards and health complaints associated with fish processing activities in India--Evaluation of a low-cost intervention. Int J Ind Ergon. 2007;37(2):125-32. doi:10.1016/j.ergon.2006.10.012.

82. Nelson A, Matz M, Chen F, Siddharthan K, Lloyd J, Fragala G. Development and evaluation of a multifaceted ergonomics program to prevent injuries associated with patient handling tasks. Int J Nurs Stud. 2006;43(6):717-33. doi:10.1016/j. ijnurstu.2005.09.004.

83. Peper E, Gibney K, Wilson V. Group Training with Healthy Computing Practices to Prevent Repetitive Strain Injury (RSI): A Preliminary Study. Appl Psychophysiol Biofeedback. 2004;29(4):279-87. doi:10.1007/s10484-004-0388-z.

84. Pillastrini P, Mugnai R, Farneti C, Bertozzi L, Bonfiglioli R, Curti S, Mattioli S, Violante FS. Evaluation of Two Preventive Interventions for Reducing Musculoskeletal Complaints in Operators of Video Display Terminals. Phys Ther. 2007;87(5):536-44.

85. Smith MJ, Bayehi AD. Do ergonomics improvements increase computer workers' productivity?: an intervention study in a call centre. Ergonomics. 2003;46(1-3):3-18. doi:10.1080/00140130303522.

86. Rogers EM. Diffusion of innovations (5th ed.). New York: FreePress; 2003.

87. Bandura A. Social foundations of thought and action: A social cognitive theory. Englewood Cliffs, NJ: Prentice-Hall; 1986.

88. Stetler CB, Brunnell, M., Giuliano, K.K., Morsi, D., Prince, L. and Newell-Stokes, V. Evidence based practice and the role of nursing leadership. J Nurs Admin 1998;28(7/8):45-53. doi:10.1097/00005110-199807000-00011.
89. Sauter SL, Swanson N. An ecological model of musculoskeletal disorders in office work. In: Moon S, Sauter, S.L., editor. Beyond biomechanics: psychosocial factors and musculoskeletal disorders in office work. London: Taylor and Francis; 1996. p3-22.

90. Rogers EM. Diffusion of innovations. New York: Free Press; 1983.

91. Nation M, Crusto C, Wandersman A, Kumpfer KL, Seybolt D, Morrissey-Kane E, Davino K. What works in prevention: Principles of effective prevention programs. Am Psychol. 2003;58(6-7):449-56. doi:10.1037/0003-066X.58.6-7.449.

92. Kristensen TS. Intervention studies in occupational epidemiology. Occup Environ Med. 2005 March 2005;62(3):205-10.

93. Armenakis AA, Bedeian AG. Organizational Change: A Review of Theory and Research in the 1990s. Journal of Management. 1999;25(3):293-315.

94. Weick KE, Quinn RE. Organizational change and development. Ann Rev Psychol. 1999;50(1):361-86. doi:10.1146/annurev.psych.50.1.361.

95. Green LW, Kreuter MW. Health promotion planning : an educational and environmental approach. Mountain View, California: Mayfield; 1991.

96. Hägg GM. Corporate initiatives in ergonomics--an introduction. Appl Ergon. 2003;34(1):3-15.doi:10.1016/ S0003-6870(02)00078-9.

97. Henning RA, Jacques, P., Kissel, G V., Sullivan, A B. Alteras-Webb, S M. Frequent short rest breaks from computer work: effects on productivity and well-being at two field sites. Ergonomics. 1997;40(1):78-91. doi:10.1080/001401397188396.

98. Christmansson M, Fridén J, Sollerman C. Task design, psycho-social work climate and upper extremity pain disorders - effects of an organisational redesign on manual repetitive assembly jobs. Appl Ergon. 1999;30(5):463-72. doi:10.1016/ S0003-6870(98)00060-X.

99. Genaidy AM, Delgado E, Bustos T. Active microbreak effects on musculoskeletal comfort ratings in meatpacking plants. Ergonomics. 1995;38(2):326-36. doi:10.1080/00140139508925107.

100. Winkel J, Westgaard RH. Editorial: A model for solving work related musculoskeletal problems in a profitable way. Appl Ergon. 1996;27(2):71-7. doi:10.1016/0003-6870(95)00061-5.

Received for publication: 2 May 2010 